\title{
Đăng ký giao dịch dân sự về chuyển quyền sở hữu bất động sản hình thành trong tương lai
}

\section{Civil transaction registration on transferring the ownership of real estate forming in the future}

\author{
Đặng Phước Thông ${ }^{1 *}$, Nguyễn Tố Uyên ${ }^{1}$ \\ ${ }^{1}$ Trường Đại học Luật Tp. HCM, Việt Nam \\ *Tác giả liên hệ, Email: dpthong@hcmulaw.edu.vn
}

THÔNG TIN

DOI:10.46223/HCMCOUJS. proc.vi.16.1.1853.2021

Ngày nhận: 7/3/2021

Ngày nhận lại: 30/3/2021

Duyệt đăng: 6/4/2021

\section{Tù khóa:}

đăng ký giao dịch, bất động sản hình thành trong tương lai, thứ tự đăng ký

Keywords:

the transaction register, real estate forming in the future, register order

\section{TÓM TẮT}

Tính ưu việt của đăng ký giao dịch dân sự về chuyển quyền sở hữu bất động sản hình thành trong tương lai được tạo ra là giúp cho người mua quyền tham gia vào xếp hạng sự cạnh tranh về quyền thu hồi bất động sản với người thứ ba nói chung và người thứ ba có đăng ký giao dịch bảo đảm nói riêng, mà các quốc gia trên thế giới đã xây dựng. Còn ở Việt Nam vẫn tồn tại hai xung đột liên quan đến đăng ký giao dịch dân sự về chuyển quyền sở hữu bất động sản hình thành trong tương lai gây bất lợi cho chủ thể có đăng ký với người thứ ba mà pháp luật hiện hành chưa có lời giải. Bài viết này tập trung làm rõ bốn nội dung: (i) Quy định về đăng ký giao dịch dân sự về chuyển quyền sở hữu bất động sản hình thành trong tương lai; (ii) So sánh pháp lý giữa đăng ký giao dịch dân sự đối với tài sản và đăng ký quyền đối với tài sản ở Việt Nam và thế giới; (iii) Những xung đột pháp luật về thứ tự xếp hạng liên quan đến đăng ký giao dịch dân sự về chuyển quyền sở hữu bất động sản hình thành trong tương lai ở Việt Nam; (iv) Kinh nghiệm nước ngoài tại Đức, Pháp và tầm nhìn xây dựng pháp luật cho Việt Nam.

\section{ABSTRACT}

The preeminence of the civil transaction registration on transferring the ownership of real estate forming in the future is to help buyers own the rights to participate in the ranking competition about gaining the rights to regain that real estate within a relationship with the third person in common and the third person who registered the secured transaction in particular, which many nations around the world have constructed. But in Viet Nam, it still exists two conflicts about this registration problem causing some disadvantages to the third person which the current laws have no explanations. This article concentrates on clarifying four contents: (i) Legal regulations about the civil transaction registration on transferring the ownership of real estate forming in the future; (ii) Legal comparision between the registration of civil transactions for properties and the registration of rights regarding properties in Vietnam and around the world; (iii) Legal conflicts about ranking order regarding the civil 
transaction registration on transferring the ownership of real estate forming in the future in Vietnam; (iv) Foreign experiences in German, France and law-making vision for Vietnam.

\section{Quy định về đăng ký giao dịch chuyển quyền sở hữu bất động sản hình thành trong tương lai}

\subsection{Loại tài sản hình thành trong tương lai đực tham gia giao dịch dân sụ về chuyển quyền sở hũu}

Tài sản Hình Thành Trong Tương Lai (viết tắt là HTTTL) là một dạng của tài sản, nó hình thành bắt nguồn từ ý tưởng mở rộng nội hàm của tài sản, không chỉ dưới dạng vật mà còn ở dạng quyền tài sản, và biểu thị của tài sản không chỉ dưới dạng hữu hình mà còn là vô hình. ${ }^{1}$ Thêm vào đó, yêu cầu mở rộng tiềm năng khai thác dạng tài sản vô hình đủ điều kiện lưu thông trong thị trường dân sự, thương mại là nhu cầu tất yếu của hình thái kinh tế xã hội hiện đại, nhằm phục vụ cho mục tiêu kích cầu kinh tế và kích cầu về thị trường tài chính (như tín dụng). Do đó, chế định tài sản HTTTL phản ánh trong Bộ Luật Dân Sự năm 2015 (viết tắt là BLDS năm 2015) như là một bước tiến lớn trong khoa học pháp lý và là sản phẩm tất yếu của sự phát triển các giao dịch dân sự (Vu \& Tuan, 2009).

Tại Điều 108 BLDS năm 2015 quy định về tài sản hiện có và tài sản HTTTL như sau: “ 1 . Tài sản hiện có là tài sản đã hình thành và chủ thể đã xác lập quyền sở hưu, quyền khác đối với tài sản truớc hoạc tại thời điểm xác lập giao dịch. 2. Tài sản hình thành trong tuoong lai bao gồm: a) Tài sản chura hình thành; b) Tài sản đã hình thành nhung chủ thể xác lập quyền sở hũu tài sản sau thời điểm xác lập giao dịch." Điều luật lấy tiêu chí thời điểm "xác lập" của "quyền sở hữu" và "giao dịch" để phân định ranh giới giữa tài sản hiện có và tài sản HTTTL. Với cách định hình này thì tồn tại 02 mốc thời điểm xảy ra: (i) nếu là việc xác lập quyền sở hữu, quyền khác đối với tài sản "trước hoặc tại thời điểm" xác lập giao dịch thì xem là tài sản hiện có; (ii) nếu là việc xác lập quyền sở hữu tài sản "sau thời điểm” xác lập giao dịch thì xem là tài sản HTTTL.

Suy rộng ra ở các loại giao dịch đối với tài sản HTTTL thì không phải loại giao dịch dân sự nào khi phát sinh cũng hướng đến xác lập quyền sở hữu, mà chỉ có những giao dịch dân sự về chuyển quyền sở hữu mới hướng đến xác lập quyền sở hữu và khi đó mới tồn tại cả hai yếu tố thời điểm "xác lập giao dịch" và thời điểm "xác lập quyền sở hữu" mà Điều 108 BLDS năm 2015 đã nêu. ${ }^{2}$ Như vậy, điểm $b$ khoản 2 Điều 108 BLDS năm 2015 đã thiết lập một nguyên tắc là thời điểm "xác lập giao dịch" phải được thực hiện trước, và tính từ thời điểm này, tài sản hiện có đó được xem là tài sản HTTTL đối với "bên nhận chuyển quyền sở hũu". Cho đến khi xảy ra thời điểm

\footnotetext{
${ }^{1}$ Tại BLDS năm 2005 mặc dù không có điều khoản quy định về tài sản HTTTL nhưng có thể nói BLDS năm 2005 đã tạo tiền đề cho sự phát triển của quy định về tài sản HTTTL khi BLDS 2005 mở rộng phạm vi của "vật". Ngoài việc bỏ quy định vật "có thực", Điều 320 BLDS năm 2005 còn gián tiếp quy định về khái niệm tài sản HTTTL trong mục bảo đảm thực hiện nghĩa vụ dân sự: "Vật hình thành trong tuoong lai là động sản, bất động sản thuộc sở hưu của bên bảo đảm sau thời điểm nghĩa vu được xác lập hoạc giao dịch bảo đảm được giao kết". Khái niệm tài sản HTTTL lần đầu tiên được quy định tại khoản 7 Điều 2 Nghị định số 165/1999/NĐ-CP ngày 19 tháng 11 năm 1999 của Chính phủ về giao dịch bảo đảm. Sau đó Khái niệm tài sản HTTTL được phát triển bởi lần lượt các nghị định như: Nghị định số 163/2006/NĐ-CP ngày 29 tháng 12 năm 2006 của Chính phủ về giao dịch bảo đảm thay thế Nghị định số 165/1999/NĐ-CP đã mở rộng hơn khái niệm tài sản HTTTL so với BLDS năm 2005 và Nghị định số 165/1999/NĐCP; Nghị định số 11/2012/NĐ-CP ngày 22 tháng 02 năm 2012 của Chính phủ về sửa đổi, bổ sung một số điều của Nghị định số 163/2006/NĐ-CP ngày 29 tháng 12 năm 2006 của Chính phủ về giao dịch bảo đảm quy định khái niệm tài sản HTTTL khá cụ thể nhưng chỉ giới hạn tài sản HTTTL là đối tượng của giao dịch bảo đảm thực hiện nghĩa vụ dân sự. Xem Nguyễn, H. K. N. (2018), Hợp đồng mua bán nhà ở hình thành trong tuoong lai theo pháp luật Việt Nam, Luận văn Thạc sĩ, Trường ĐH Luật TP. Hồ Chí Minh, tr. 9-11.

${ }^{2}$ VD: Giao dịch cho thuê, cho thuê lại tài sản, giao dịch bảo đảm thì không được tính vào việc xác định tài sản HTTTL, còn giao dịch chuyển đổi, chuyển nhượng, tặng cho, thừa kế thì được tính vào việc xác định tài sản HTTTL.
} 
“xác lập quyền sở hũu" chính thức, thì tài sản HTTTL lại trở về hình dáng là tài sản hiện có theo khoản 1 Điều 108 BLDS năm 2015.

Tuy nhiên khái niệm tại Điều 108 BLDS năm 2015 không đúng với dạng tài sản là "Nhà, công trình xây dưng", bởi lẽ tiêu chí để xác định "Nhà, công trình xây dựng hình thành trong tuoong lai" lại dựa trên yêu tố thời điểm "nghiệm thu đura vào sủ dụng" chứ không phải là thời điểm "xác lập quyền sở hũu tài sản sau thời điểm xác lập giao dịch". Cụ thể là Khoản 19 Điều 3 Luật Nhà ở năm 2014 quy định: "Nhà ở hình thành trong turơng lai là nhà ở đang trong quá trình đầu tu xây dựng và chưa được nghiệm thu đura vào sủ dụng”. Còn Quốc hội (2014) thì phân chia nhà ở thành nhà ở có sẵn và nhà ở HTTTL (khoản 3 , khoản 4 Điều 3). Khoản 4 Điều 3 Luật Kinh doanh bất động sản năm 2014 quy định: "Nhà, công trình xây dụng hình thành trong tương lai là nhà, công trình xây dựng đang trong quá trình xây dựng và chưa đượ nghiệm thu đưa vào sủ dụng”.

Như vậy, chỉ khi Bất Động Sản (viết tắt là BĐS) HTTTL đảm bảo điều kiện là: "Tài sản đã hình thành nhưng chủ thể xác lập quyền sở hưu tài sản sau thời điểm xác lập giao dịch" (bao gồm cả: quyền sở hữu quyền sử dụng đất) và điều kiện riêng đối với bất động sản là "nhà, công trình xây dưng đang trong quá trình xây dưng và chua được nghiệm thu đưa vào sư dụng", thì BĐS HTTTL đó được phép tham gia giao dịch dân sự về chuyển quyền sở hữu, giống như dạng tài sản đã hình thành.

Người viết cho rằng, dù có mâu thuẫn trong tiêu chí xác định thế nào là "bất động sản hình thành trong tương lai" ở luật chuyên ngành, nhưng với những quy định vừa nêu thì chúng rất có ý nghĩa trong việc thiết lập một giả định pháp lý về chuyển đổi trạng thái pháp lý của tài sản ${ }^{3}$ trong hành trình chuyển quyền sở hữu từ chủ thể này sang chủ thể khác. ${ }^{4}$ Vấn đề đặt ra là, nếu bước đầu chúng ta đã có quy định các tiêu chí làm nền tảng để khoanh vùng dạng BĐS HTTTL, thì bước tiếp theo chúng ta tìm hiểu các loại giao dịch dân sự đối với BĐS HTTTL nào có quy định về đăng ký?

\subsection{Loại giao dịch dân sụ về chuyển quyền sở hũu bất động sản hình thành trong tương lai có quy định về đăng $k \dot{y}$}

Xét dưới góc độ về đăng ký, thì không phải bất cứ BĐS HTTTL nào khi "xác lập giao dịch" chuyển quyền sở hữu cũng được quy định đăng ký. Do đó, khi xét đến đăng ký giao dịch dân sự về chuyển quyền sở hữu BĐS HTTTL, thì phải xét đến dạng BĐS cụ thể nào có quy định về đăng ký (bắt buộc hay theo yêu cầu) và những loại giao dịch nào BĐS đó được quy định là đăng ký.

Pháp luật hiện hành quy định hai loại BĐS hữu hình bắt buộc đăng ký (VD: quyền sử dụng đất) và đăng ký theo yêu cầu (VD: quyền sở hữu đối với tài sản khác gắn liền với đất, như nhà ở, căn hộ chung cư, và quyền sở hữu trí tuệ). Theo đó, nếu trong điều kiện "xác lập giao dịch" chuyển quyền sở hữu xảy ra theo điểm b khoản 1, Điều 108 BLDS năm 2015, thì hai loại BĐS hữu hình này trở thành BĐS HTTTL. Khi đó, sẽ xảy ra hai trường hợp đối với giao dịch BĐS HTTTL là: (i) giao dịch dân sự về chuyển quyền sở hữu được xác lập và sau đó buộc phải đăng ký quyền sở hữu chính thức (VD: quyền sở hữu quyền sử dụng đất); và (ii) giao dịch dân sự về chuyển quyền sở hữu được xác lập nhưng không buộc phải đăng ký quyền sở hữu chính thức, mà quyền sở hữu

\footnotetext{
${ }^{3}$ Khi trạng thái pháp lý của tài sản này thay đổi không có nghĩa đối tượng chuyển đổi biến mất hoặc xuất hiện, mà đối tượng chuyển đổi là tài sản đó vẫn tồn tại trong thế giới quan.

${ }^{4}$ Việc thừa nhận sự chuyển đổi pháp lý này giúp ích cho bên bán (hoặc chủ đầu tư) có thể bán được BĐS này để gia tăng kinh tế, tăng vốn, hoặc tăng lợi nhuận. Bên cạnh đó, người mua cũng sử dụng được BĐS này để tham gia vào thị trường tài chính nhằm tiếp cận được vốn vay, và dùng $\mathrm{BĐS}$ này để đảm bảo nghĩa vụ thanh toán, tương tự như dạng tài sản bảo đảm đã hình thành.
} 
có thể xác lập theo thời điểm thỏa thuận trong hợp đồng, ${ }^{5}$ công chứng, chứng thực (VD: giao dịch dân sự về chuyển quyền sở hữu tài sản khác gắn liền với đất, giao dịch dân sự về chuyển quyền sở hữu căn hộ chung cư). Các vấn đề bảo vệ bên mua tài sản HTTTL lúc này được quy chiếu đến các thỏa thuận trong hợp đồng. Tuy nhiên, xét rằng trong quan hệ hợp đồng chỉ có thể ràng buộc hiệu lực pháp lý đối với đôi bên, mà không thể áp đặt hệ quả buộc phải biết với bên thứ ba có tham gia đăng ký bảo đảm (VD: đăng ký thế chấp); hoặc người thứ ba có đăng ký quyền khác đối với tài sản theo Điều 106 BLDS năm 2015 (VD: đăng ký quyền sử dụng hạn chế thửa đất liền kề), ${ }^{6}$ thì lúc này bên mua trong hợp đồng là bên yếu thế hơn về thu hồi tài sản khi nảy sinh tranh chấp.

Trên thực tế, quy định về loại giao địch dân sự do chủ thể thực hiện các quyền đối với BĐS HTTTL, mà có quy định tham gia đăng ký phần lớn được quy định trong Luật Đất đai, Luật Nhà ở và Luật Kinh doanh BĐS. Chẳng hạn, điểm a khoản 4 Điều 95 Luật Đất đai năm 2013 quy định: "Nguoơi sử dụng đất, chủ sở hũu tài sản gắn liền với đất thực hiện các quyền chuyển đổi, chuyển nhương, cho thuê, cho thuê lại, thì̀a kế, tặng cho quyền sử dụng đất, tài sản gắn liền với đất; thế chấp, góp vốn bằng quyền sử dưng đất, tài sản gắn liền với đất". Quy định này đề cập vấn đề về đăng ký biến động, trong đó điều chỉnh các dạng giao dịch dân sự được hình thành do chủ thể khi thực hiện các quyền liên quan đến đất thì phải tham gia vào đăng ký biến động. Các giao dịch dân sự này có thể phân thành hai nhóm là:

(i) Giao dịch dân sự về chuyển quyền sở hữu quyền sử dụng đất, và quyền sở hữu tài sản gắn liền với đất gồm "quyền chuyển đổi, chuyển nhuợng, thùra kế, tặng cho", vì các dạng giao dịch dân sự này có nội dung chuyển toàn bộ quyền năng nắm giữ quyền sử dụng đất, quyền sở hữu tài sản gắn liền với đất sang cho chủ thể khác;

(ii) Giao dịch dân sự khác đối với đất, tài sản gắn liền với đất là "cho thuê, cho thuê lại, thế chấp, góp vốn bằng quyền sủ dụng đất, tài sản gắn liền với đất”, vì các dạng giao dịch dân sự này mang bản chất chia cắt quyền năng cho chủ thể khác khai thác nhưng không mất đi toàn bộ quyền năng nắm giữ quyền sử dụng đất của mình và chủ đất có thể khôi phục lại toàn quyền sử dụng đất khi các giao dịch dân sự trên chấm dứt.

Như vậy quy định vừa nêu cho thấy, hai nhóm giao dịch này do có đối tượng là "đất, tài sản gắn liền với đất" nên chúng thuộc đối tượng của đăng ký biến động được Luật Đất đai quy định.

Thư nhất, về bất động sản hình thành trong tưong lai là quyền sở hũu quyền sử dụng đất, thì đối với khoản 2 Điều 108 BLDS năm 2015 quy định rằng tài sản HTTTL có thể là "tài sản đã hình thành nhưng chủ thể xác lập quyền sở hưu tài sản sau thời điểm xác lập giao dịch". Kết hợp quy định này với các quy định nêu trên cho trường hợp thực tế là chủ đầu tư phân lô bán nền quyền sở hữu quyền sử dụng đất thông qua hợp đồng mua bán đất có công chứng hợp pháp, thì từ thời điểm công chứng cho đến khi được cấp giấy chứng nhận quyền sở hữu quyền sử đụng đất đó đặt trong tình trạng "quyền sở hũu quyền sủ dụng đất HTTTL" đối với bên mua. Bởi lẽ, việc công chứng hợp pháp sẽ bảo đảm cho giao dịch dân sự về đất có hiệu lực, nhưng quyền đối với đất đó chưa chính thức chuyển cho bên nhận chuyển quyền. Do đó, bên nhận chuyển quyền được sử dụng

\footnotetext{
${ }^{5}$ Thời điểm xác lập quyền sở hữu tài sản (nói chung) theo giao dịch, ở đây, nếu chiếu theo tiêu chí tại điểm b khoản 1 Điều 108 BLDS năm 2015 thì ngay lập tức tài sản đó sẽ chuyển thành tài sản hiện có, bởi vì nó thỏa mãn quyền sở hữu đã được xác lập chính thức từ nội dung của hợp đồng có hiệu lực. Tuy nhiên, nếu chiếu theo tiêu chí "thời điểm nghiệm thu" ở khoản 19 Điều 3 Luật Nhà ở năm 2014 và khoản 4 Điều 3 Luật Kinh doanh bất động sản năm 2014 đối với tài sản nhà ở và công trình trên đất thì, thời điểm xác lập quyền sở hữu theo giao dịch không tác động đến chuyển đối trạng thái tài sản, mà nó vẫn ở trạng thái nhà ở và công trình trên đất HTTTL.

${ }^{6}$ Chẳng hạn điểm 1 khoản 4 Điều 95 Luật Đất đai năm 2013 bắt buộc đăng ký biến động áp đụng đối với việc: “l) Xác lập, thay đổi hoạc chấm dưt quyền sử dụng hạn chế thửa đất liền kềे;"
} 
bản công chứng để tham gia đăng ký biến động.

Đối chiếu với các dạng giao dịch dân sự về chuyển quyền sở hữu quyền sử dụng đất ở nhóm (i) nêu trên, thì đối tượng đăng ký biến động lúc này được xác định là “đăng ký giao dịch dân sự về chuyển quyền sở hữu quyền sử dụng đất HTTTL". Bởi vì, từ thời điểm người mua nộp các tài liệu minh chứng (hợp đồng mua bán đất với chủ đầu tư) để đăng ký biến động, cho đến khi được cấp giấy chứng nhận chủ quyền đất chính thức, thì còn trải qua một thời gian khá dài tùy vào các tiêu chuẩn hành chính (VD: tiêu chuẩn về xây dựng, tiêu chuẩn về quy hoạch, tiêu chuẩn về địa chính). Cho nên, thời điểm nộp tờ khai đăng ký biến động và thời điểm được công nhận chuyển quyền sở hữu quyền sử dụng đất chính thức là hai thời điểm độc lập và có hàm nghĩa khác nhau.

Thời điểm nộp tờ khai đăng ký biến động có thể được giải thích là thời điểm nắm giữ quyền ưu tiên mà trong tương lai quyền sử dụng đất sẽ chuyển giao chính thức, là thời điểm phát sinh chế định bảo vệ bởi điều khoản người thứ ba ngay tình theo Điều 133 BLDS năm 2015, là thời điểm có thể được tính để xếp hạng về đối kháng về quyền với chủ thể khác, thậm chí giải phóng các quyền lợi người thứ ba đang có trên tài sản đó (VD: người bán cũng bán cho người khác mà không đăng ký chuyển quyền hoặc người bán đang vay khoản tiền nhưng không đăng ký bảo đảm).

Còn thời điểm được cấp giấy chứng nhận quyền sử dụng đất là thời điểm mà chủ đất có đầy đủ quyền năng để thực thi quyền sử dụng đất của mình. Lúc này quyền sử dụng đất không được xem là tài sản HTTTL, mà được phục hồi trạng thái tài sản hiện có. Do đó, thật không cần thiết nếu mang so sánh hiệu lực pháp lý giữa hai thời điểm đăng ký lần đầu với đăng ký biến động, bởi vì suy cho cùng thì chúng có hiệu lực pháp lý là ngang nhau. Thêm vào đó, hệ quả khi được cấp giấy chứng nhận quyền sử dụng đất, chủ đất còn được phép chia cắt quyền năng cho người khác như: quyền hưởng dụng, quyền bề mặt, quyền đối với BĐS liền kề, mà ở giai đoạn hợp đồng mua bán chưa thể phân chia được.

Ở nhóm (ii) là giao dịch dân sự khác đối với đất, thì khi chủ thể thực hiện quyền "cho thuê, cho thue lại, thế cháp, góp vốn bằng quyền sủ dụng đất", cũng được Luật Đất đai quy định tham gia đăng ký nhằm thống nhất quản lý các thông tin pháp lý liên quan đến đất đai, phục vụ cho việc tra cứu và giải quyết các tranh chấp liên quan đến đất. Tuy nhiên, các giao dịch dân sự kể trên áp dụng đối với đất hiện có, tức là đối với chủ đất đang nắm giữ toàn bộ quyền năng về sử dụng đất mà không thể áp dụng đối với quan hệ về BĐS HTTTL. Bởi vì các giao dịch dân sự trên không mang nội dung xác lập quyền sở hữu quyền sử dụng đất mà chỉ chia sẻ quyền khai thác về đất, nên không đảm bảo điều kiện về tài sản HTTTL theo điểm a khoản 4 Điều 95 Luật Đất đai năm 2013. Do đó, đối tượng đăng ký này được xác định lúc này là “đăng ký giao dịch dân sụ khác đối với quyền sử dụng đất hiện có"

Thư hai, về bất động sản hình thành trong tương lai là quyền sở hũu tài sản khác gắn liền với đất, thì nếu "tài sản khác gắn liền với đất" đã ở dạng hữu hình nhưng chủ đầu tư cũng bán quyền sở hữu nhà ở và công trình trên đất (căn hộ chung cư) thông qua hợp đồng mua bán có công chứng hợp pháp, thì từ thời điểm công chứng cho đến khi được cấp giấy chứng nhận quyền sở hữu, quyền sở hữu đó cũng đặt trong tình trạng quyền sở hữu tài sản khác gắn liền với đất HTTTL.

Hiện nay, loại giao dịch dân sự về chuyển quyền phổ biến nhất là hợp đồng mua bán nhà ở HTTTL có đối tượng là một tài sản đặc biệt, nhà ở chưa được nghiệm thu đưa vào sử dụng vào thời điểm giao kết hợp đồng. ${ }^{7}$ Trên thị trường hiện nay, BĐS HTTTL được mua bán phổ biến là

\footnotetext{
${ }^{7}$ Do các đặc tính đặc biệt của nhà ở HTTTL đã làm cho hoạt động mua bán nhà ở HTTTL cũng có những điểm khác biệt so với các hoạt động kinh doanh thông thường khác như tính rủi ro cao, chịu sự chi phối mạnh mẽ của pháp luật... Các đặc tính đặc biệt này cũng làm cho hợp đồng mua bán nhà ở HTTTL khác biệt so với các loại hợp đồng khác về chủ thể, đối tượng, nội dung hợp đồng... Xem: Nguyễn, H. K. N., tlđd, tr. 17-18.
} 
căn hộ chung cư, nhà ở thương mại,... (gọi chung là nhà ở), chúng được bán bởi chủ đầu tư, thông qua sự cho phép của Luật Kinh doanh BĐS, Luật Nhà ở, Luật Đất đai và Luật Đầu tư. Tuy nhiên, khác với nhà ở có sẵn thì nhà ở HTTTL không thể tham gia các giao dịch đầy đủ vào các loại giao dịch như "cho thuê mua, tặng cho, đổi, góp vốn bằng nhà ơ"” theo quy định của điểm a khoản 1 Điều 118 Luật Nhà ở 2014, bởi vì điều kiện bắt buộc để tham gia các giao dịch này là "phải có giấy chứng nhận theo quy định của pháp luật". Tuy nhiên, ngoại lệ chỉ có ở 02 loại giao dịch nhà ở HTTTL được phép tham gia là "mua bán, thế chấp" (điểm a khoản 2 Điều 118 Luật Nhà ở năm 2014): (i) Đối với hợp đồng mua bán nhà ở HTTTL, thì đối tượng của hợp đồng mua bán nhà ở HTTTL có thể là nhà ở riêng lẻ hoặc nhà chung cư (khoản 3 Điều 3 Luật Nhà ở 2014); (ii) Đối với giao dịch thế chấp, thì nhà ở HTTTL chính là đối tượng của thế chấp để bảo đảm nghĩa vụ.

Tuy nhiên, trong hai loại giao dịch đề cập trên thì chỉ có thế chấp là được phép tham gia đăng ký, ${ }^{8}$ còn đăng ký giao dịch mua bán nhà ở HTTTL thì chưa được quy định, dẫn đến sự thiếu cân bằng giữa những người thứ ba có cùng lợi ích trên cùng một đơn vị tài sản. Bởi vì, trong đăng ký thế chấp, thì bên nhận thế chấp được bảo vệ bởi tính đối kháng, nhưng trong quan hệ giao dịch dân sự về chuyển quyền sở hữu nhà ở HTTTL thì người mua không được bảo vệ bởi bất cứ điều khoản đối kháng quyền nào về đăng ký để cạnh tranh với bên đăng ký thế chấp. Vấn đề này trên thực tế xảy ra khá phổ biến, điển hình là chủ đầu tư đã bán căn hộ cho khách hàng thu đủ tiền, nhưng rồi lại mang dự án, căn hộ HTTTL thế chấp ngân hàng để vay vốn, gây ảnh hưởng đến quyền lợi của khách hàng, ${ }^{9}$ hay trường hợp bán nhà mà vẫn thế chấp, chủ đầu tư không thông báo với khách hàng là dự án đã thế chấp và không giải chấp căn hộ đã bán như dự án The Harmona tại TP. HCM trước đây. ${ }^{10}$

Như vậy, với những phân tích nêu trên thì có thể khẳng định, chỉ có nhóm (i) giao dịch dân sự về chuyển quyền sở hữu quyền sử dụng đất và quyền sở hữu tài sản gắn liền với đất là những giao dịch dân sự về chuyển quyền sở hữu BĐS HTTTL có quy định đăng ký. Tuy nhiên, về nguyên tắc đất đai là đăng ký bắt buộc và tài sản khác gắn liền với đất là đăng ký theo yêu cầu, nhưng điểm a khoản 4 Điều 95 Luật Đất đai năm 2013 lại gộp các loại giao dịch đối với “đất, tài sản gắn liền với đất" vào chung một nhóm để thực hiện đăng ký biến động là không phù hợp. Dẫn đến nhận thức rằng, việc tổ chức đăng ký biến động ${ }^{11}$ giao dịch dân sự về chuyển quyền sở hữu là áp dụng chung cho cả "đất, tài sản gắn liền với đất" cũng đều là bắt buộc, lại mâu thuẫn với Luật Nhà ở năm 2014 là đăng ký theo yêu cầu giao dịch dân sự về chuyển quyền sở hữu đối với nhà ở, căn hộ - tài sản gắn liền với đất. Hơn nữa, xét thời điểm đăng ký giao dịch dân sự về chuyển quyền sở hữu quyền sử dụng đất được xác lập thì phải chờ đến khi được cấp giấy chứng nhận thì quyền sử dụng đất mới được xác lập, ${ }^{12}$ nhưng quyền sở hữu nhà ở, căn hộ thì đã có thể nảy sinh từ hợp đồng mua bán theo Luật Nhà ở chứ không nhất thiết là từ khi được cấp giấy chứng nhận. ${ }^{13}$

\footnotetext{
${ }^{8}$ Điều 4 Nghị định số 102/2017/NĐ-CP ngày 01/9/2017 của Chính phủ về đăng ký biện pháp bảo đảm.

9 Trần, Y. (2019). Ngăn chặn việc chủ đầu tư thế chấp căn hộ đã bán, Sài Gòn giải phóng Online. https://www.sggp.org.vn/ngan-chan-viec-chu-dau-tu-the-chap-can-ho-da-ban-582173.html, truy cập ngày 25/6/2020. ${ }^{10}$ Trang, V. (2019). , Dự án thế chấp ngân hàng: Khách hàng có rủi ro?. Báo Đầu tu Bất động sản. Retrieved from https://bds.tinnhanhchungkhoan.vn/bat-dong-san/du-an-the-chap-ngan-hang-khach-hang-co-rui-ro-220911.html, truy cập ngày $25 / 6 / 2020$.

${ }^{11}$ Lưu ý rằng việc tổ chức đăng ký và hệ quả đối kháng của người được đăng ký là hai vấn đề pháp lý khác nhau. Bởi tùy vào đối tượng đăng ký là gì thì tương ứng với sự minh định đối với hệ quả đối kháng đó. Chẳng hạn đối tượng đăng ký bắt buộc có hệ quả đối kháng mạnh hơn, còn đối tượng đăng ký theo yêu cầu có hệ quả đối kháng thấp hơn.

${ }^{12}$ Luật Đất đai năm 2013 xác định "việc đăng ký đất đai, tài sản gắn liền với đất có hiệu lục kể tù thời điểm đăng ký vào Sổ địa chính" (khoản 4 Điều 95 Luật Đất đai năm 2013).

${ }^{13} \mathrm{Cu}$ thể, có 05 thời điểm có thể làm phát sinh quyền sở hữu nhà ở: (i) xác lập quyền sở hữu nhà ở từ thời điểm đủ thời hiệu chiếm hữu (Điều 236 BLDS năm 2015); (ii) xác lập quyền sở hữu nhà ở từ thời điểm bên mua nhận bàn giao nhà ở hoặc kể từ thời điểm bên mua thanh toán đủ tiền mua nhà ở cho chủ đầu tư (Điều 12 Luật Nhà ở năm 2014); (iii) xác lập quyền sở hữu nhà ở từ thời điểm công chứng, chứng thực (khoản 1 Điều 122 Luật Nhà ở năm 2014); (iv)
} 
Tóm lại, liên quan đến giao dịch dân sự đối với BĐS hình thành trong tương lai thì chỉ có hai dạng đáp ứng đủ điều kiện để tham gia đăng ký là: "đăng ký giao dịch dân sụ về chuyển quyền sở hưu quyền sử dụng đất HTTTL, quyền sở hưu tài sản khác gắn liền với đất HTTTL". Tuy nhiên, chúng ta đã biết rằng trên một đơn vị BĐS có thể cùng tồn tại thêm một chủ thể đăng ký giao dịch bảo đảm, hoặc chủ thể có đăng ký quyền khác đối với BĐS với chủ thể có “đăng ký giao dịch dân sụ về chuyển quyền sở hũu BĐS HTTTL". Điều này sẽ tạo nên hai xung đột về thứ tự xếp hạng đăng ký sẽ được tác giả làm rõ ở phần dưới. Chính vì lẽ đó, việc quan tâm đến xây dựng và hoàn thiện khung pháp lý cho đăng ký giao dịch dân sự về chuyển quyền sở hữu BĐS HTTTL là cần thiết và khẩn trương, nó không chỉ hướng đến sự minh bạch về thông tin trong xếp hạng quyền thu hồi tài sản, mà còn để ngăn chặn hành vi nêu trên của chủ đầu tư. Tuy nhiên, để giải quyết về bài toán xếp hạng đăng ký, thì chúng ta cùng tìm hiểu về bản chất pháp lý giữa đăng ký giao dịch và đăng ký quyền, để làm cơ sở đánh giá các xung đột đối kháng với người thứ ba khi có nhiều chủ thể tham gia đăng ký.

\section{Lịch sử vấn đề đăng ký và so sánh pháp lý giữa đăng ký giao dịch dân sự đối với tài sản với đăng ký quyền đối với tài sản ở Việt Nam và thế giới}

\subsection{Nguồn gốc hình thành của đăng ký giao dịch và đăng ký quyền đối với tài sản}

Bắt đầu từ phân tích của Foucault (1969), cho rằng, đăng ký ban đầu tồn tại dưới dạng các tài liệu lưu trữ hay gọi là dạng danh sách đơn giản, được định nghĩa là "hệ thống tổng quát cho việc hình thành và chuyển đổi các tuyên bố đối với tài sản”. Vào khoảng 2300 năm trước Công nguyên, "khái niệm luu trü" xuất hiện dưới dạng bản đồ đất sét Mesopotamian, trong bối cảnh mảnh đất bán được vẽ lại phần hiện trạng và đặc điểm pháp lý. Ý nghĩa khái niệm lưu trữ được Soto lập luận năm 2001 rằng, đó là bước tiến quan trọng, vì "căn bản là tạo ra sự phân biệt giữa ngôi nhà và quyền sở hũu ngôi nhà. Ngôi nhà nằm trong một thế giới vật chất, hữu hình, nhung quyền sở hưu nằm trong một thế giới khái niệm”. Khái niệm này tiếp tục hoàn thiện trong các cuốn sách cầm cố Attican và các bộ sưu tập tài liệu theo trình tự thời gian ở tỉnh La Mã thuộc Ai Cập. Các tiền thân được biết đến là các sổ đăng ký đất đai hiện tại ở Đức bắt đầu từ năm 500 sau Công nguyên, đây là những hồ sơ đầu tiên xác định quyền đối với thu nhập từ các tài sản riêng biệt, giới hạn trong các loại tài sản đăng ký và đặt tên cho chủ thể được phép nắm giữ tài sản Harald (2012). Khái niệm có tác động lớn đến sự hình thành hệ thống đăng ký khế ước ${ }^{14}$ đầu tiên (Hanstad, 1998). vào thời sơ khai kinh tế nông nghiệp. Các dấu vết cho thấy, hợp đồng được ký kết đầu thiên niên kỷ thứ ba trước Công nguyên và loài người đã có nhu cầu cần được bảo đảm trong sử dụng đất mà họ khai hoang. Kinh Thánh kể lại, một giao dịch đất đai rất sớm khi mua một cánh đồng, được đóng dấu và soạn thảo phù hợp với các quy định pháp luật. ${ }^{15}$ Kết quả này tạo ra hệ thống các bảng ghi nhận chính thức về quyền chủ đất tồn tại trải dài tới năm 3000 trước Công nguyên. Tiếp đó, ở thời Ai Cập cổ đại, người ta lập Sổ đăng ký Hoàng gia để ghi nhận QSDĐ cho mục đích thu thuế

xác lập quyền sở hữu nhà ở do các bên thỏa thuận trong hợp đồng (khoản 2 Điều 122 Luật Nhà ở năm 2014); (v) xác lập quyền sở hữu nhà ở từ thời điểm hợp đồng được ký kết (khoản 2 Điều 122 Luật Nhà ở năm 2014). Xem: Đặng, P. T. (2020). Đăng ký quyền sở hữu căn hộ chung cư theo yêu cầu và một số kiến nghị nhằm hoàn thiện pháp luật. Tạp chí Khoa hoc pháp lý Việt Nam, 3, tr. 44.

14 "Khế uớc là hợp đồng trao đổi tài sản hoạc dịch vụ mà các chi phí không thể tránh được tù việc đáp ứng các nghĩa vu theo hợp đồng vuợt quá lợi ích kinh tế dự tính thu được tù hợp đồng đó ".

Xem tại: http://www.ifac.org/system/files/downloads/translation_db_file_16.pdf, truy cập ngày 01/6/2018, tr. 15.

15 “9. Tôi đã mua cánh đồng của con trai của chú của Hanameel, đó là ở Anathoth, và số tiền cân được đã đura cho anh ta, là muời bảy đồng bạc. 10. Tôi đã đăng ký các bằng chưng, niêm phong nó, và lấy các nhân chứng, và nói với anh ta về số tiền du. 11. Vì vậy, tôi lấy bằng chứng về việc mua, gồm cả hai thứ là cái đã được niêm phong theo luật pháp và thêm các bằng chứng bổ sung. 12. Tôi đã đưa ra bằng chứng về việc mua cho Baruch con trai của Neriah, con trai của Maaseiah, trước mặt con trai của chú Hanameel, để ho là nhũng nhân chúng xác thục nội dung mua trong đăng ký làm bằng chứng, trước tất cả nhũng người Do Thái mà ngồi trong tòa án của nhà tù.”. Xem Sách Kinh thánh Jeremiah, chương 32, đoạn 9-12. 
Larsson (1991). Sau đó rất lâu tại châu Âu, các ghi nhận về đất đai cũng được tập hợp cho mục đích thu thuế. Hệ thống này đến nay vẫn tồn tại rõ nét tại Hoa Kỳ, được gọi là đăng ký "ghi nhận đất đai" (land recordation) - đôi khi được gọi là một bảng tóm tắt của quyền sở hữu cho thấy lịch sử giao dịch (Dongwoo \& Richard 2010), gồm các hoạt động đăng ký hoặc ghi nhận các tài liệu ảnh hưởng tới lợi ích trên đất.

Sau năm 900, ý tưởng xuất phát từ hoạt động buôn bán BĐS sôi động tại các đô thị, làm gia tăng nhu cầu tạo ra một hệ thống đăng ký tài sản dễ lĩnh hội. Vào cuối thời Trung cổ, các thành phố lớn được xem là một thành trì pháp lý, hay một "thành phố luật" ban bố các đạo luật để điều chỉnh riêng về đăng ký tài sản. Do đó, lần đầu tiên, đăng ký tài sản là cấu tạo của một quyền, "thành phố luật" đã quyết định tạo ra nó. Đây là bước tiến quan trọng đối với khái niệm, vốn ban đầu chỉ nhằm mục đích đăng ký để lưu trữ. Khái niệm pháp lý đã được mở rộng từ một bản đăng ký chứng minh sang quyền đăng ký vào sổ đăng ký. Từ năm 1500 trở đi, việc sử dụng sổ đăng ký bị giảm, do việc thông qua luật La Mã, bởi nó không đưa ra bất kỳ luật thủ tục nào liên quan đến việc mua tài sản và đăng ký không còn coi là quan trọng nữa. Đến năm 1872, các quyền đăng ký được khôi phục trong Bộ luật Đăng ký đất của Prussian - Phổ, ghi rõ đối tượng đăng ký là tất cả các quyền về tài sản cho đăng ký lần đầu và phân chia thành ba dạng quyền để tổ chức đăng ký. Điều này tạo nên một khởi điểm mới để các quyền đối với đất đai được đăng ký và xác lập "thực sự” (Harald, 2012).

\section{2. Đặc điểm pháp lý giữa đăng ký giao dịch dân sụ̂ về chuyển quyền đối với tài sản và đăng ký quyền đối với tài sản}

Khi học thuyết quyền đối vật xuất hiện trong luật La Mã, tạo nên sự tiến hóa nhiều quyền đối vật (không phải là quyền sở hữu) và sự mở rộng của khoa học pháp lý quyền sở hữu đối với tài sản hiện có, vô hình, hoặc có yếu tố "gắn liền" hoặc không thể tách rời, làm thay đổi cách định hình hệ thống đăng ký tài sản trên thế giới. Các dạng quyền này tồn tại trong thỏa thuận các bên, thậm chí là một lợi ích với chủ thể thứ ba. ${ }^{16}$ Chúng tác động đến những khác biệt ở mỗi quốc gia khi định hình quyền này trong hệ thống đăng ký. ${ }^{17}$ Từ đó, xuất hiện hai nhánh đăng ký khế ước/ giao dịch về tài sản và đăng ký quyền đối với tài sản. Dưới đây là những điểm chung và riêng biệt của hai hệ thống đăng ký này.

\subsubsection{Bốn đặc tính giống nhau của đăng ký giao dịch dân sụ về chuyển quyền đối với tài} sản và đăng ký quyền đối với tài sản

(i) Tính lưu trữ. Lưu trữ là nhu cầu đầu tiên của hệ thống đăng ký tài sản, bởi ban đầu đăng ký hướng đến việc lưu trữ lịch sử các giao dịch về đất và tập hợp các giao dịch nhằm phục vụ cho mục đích thu thuế. Sau đó, các thành lũy đã phát triển yếu tố lưu trữ thành yếu tố xác định quyền thực chứ không đơn thuần là tập hợp các bản giao dịch nữa. Nhưng, dù đăng ký được áp dụng để tập hợp các giao dịch hay tạo ra quyền cho người đăng ký, thì tính lưu trữ luôn tồn tại cả hai nhánh của đăng ký tài sản. Bởi, tính lưu trữ không chỉ nhằm phục vụ cho việc tra cứu chính xác chủ thể nắm quyền sở hữu, mà còn sử dụng để xác định hệ quả dân sự về tài sản theo các thời điểm biến động quan hệ trên tài sản. ${ }^{18}$

\footnotetext{
${ }^{16}$ VD: quyền phát sinh từ một khoản nợ như thế chấp, hoặc nợ phí chậm trả tại Đức; hay quyền phát sinh từ một ủy quyền sở hữu lâu dài như cho thuê quyền sở hữu lâu dài tại Pháp.

${ }^{17}$ VD: Tại Đức, Úc, Pháp có thể chuyển hóa quyền trong giao dịch sang quyền thực được đăng ký, còn ở Hoa Kỳ thì chỉ cho phép đăng ký dưới dạng khế ước chứ không xác định trạng thái về quyền.

${ }^{18}$ Chẳng hạn, tại Hoa Kỳ, đăng ký khế ước không cung cấp trạng thái về quyền nhưng nó giúp việc tra cứu quyền sở hữu về đất được rút ngắn, nhất là khi đất được chuyển dịch hàng trăm năm qua nhiều thế hệ. Tại Pháp thì sự tra cứu vô cùng quan trọng đối với Công chứng viên bởi họ có trọng trách rất lớn trong việc thương thuyết ba bên (người bán, người mua và người có quyền lợi đã đăng ký), nên trước khi tài sản được bán cho người mua thì quyền lợi của người thứ ba có đăng ký sẽ được đàm phán giải quyết (hoặc chuyển giao cho người mua hoặc hoàn tất khoản nợ). Tại Đức
} 
(ii) Tính đăng ký. Đây là công cụ giúp đối tượng đăng ký tiếp cận với sức mạnh bảo vệ của pháp luật và loại bỏ khả năng xâm phạm đến chúng, trừ trường hợp gian lận thực sự có thể chứng minh được. Chẳng hạn, trong đăng ký giao dịch, đối tượng đăng ký chính là các tài liệu giao dịch chứa đựng các quyền và nghĩa vụ của các bên, và trong quan hệ trực tiếp với dạng quyền năng cụ thể trên tài sản (VD: hợp đồng cho thuê xây dựng hoặc hoặc hợp đồng thuê đất) hoặc quyền đòi nợ (hợp đồng thế chấp), nếu các giao dịch đó có đăng ký, thì các quyền và nghĩa vụ trong giao dịch đó chỉ có thể phá vỡ khi người đăng ký tự xóa bỏ đăng ký. Ngược lại, giao dịch không đăng ký thì có thể bị một trong các bên hoặc bên thứ ba có lợi ích liên quan phá vỡ và bồi thường theo chế định về hợp đồng. Tương tự với đăng ký quyền đối với tài sản, đối tượng đăng ký là quyền sở hữu và quyền khác đối với tài sản, nếu các quyền năng này được đăng ký, chúng sẽ được sự bảo vệ tuyệt đối từ pháp luật. ${ }^{19}$

(iii) Tính thông tin. Đặc tính này hướng đến cung cấp các thông tin truy dẫn về danh tính chủ thể, phạm vi nắm giữ các lợi ích, hạn chế quyền trên tài sản cũng như các yêu cầu chủ thể khác trong mối quan hệ trên tài sản đó. Tuy nhiên có khác biệt đôi chút giữa thông tin được cung cấp bởi đăng ký quyền và đăng ký giao dịch. Trong đăng ký quyền, thông tin về một quyền lợi khi được cung cấp, thì thông tin đó sẽ có giá trị và chính xác tuyệt đối, nó được đảm bảo bởi chính phủ và nếu có sai lệch, chính phủ có trách nhiệm bồi thường thỏa đáng. ${ }^{20}$ Còn trong đăng ký giao dịch, thông tin được cung cấp chỉ tuyên bố với thế giới rằng giao dịch tồn tại (Samantha, 2001), và chính phủ không khẳng định sự tồn tại của quyền trên tài sản cho chủ thể đăng ký, và khi thông tin sai lệch thì việc bồi thường sẽ do cơ quan bảo hiểm tư nhân chi trả, nếu như người đó có tham gia vào bảo hiểm về quyền lợi. ${ }^{21}$

(iv) Tính ưu tiên. Khả năng ưu tiên là sự khác biệt giữa việc đăng ký và không đăng ký. Nó mang lại ưu thế cho chủ thể tham gia vào đăng ký và biểu hiện cho sự tự do của nền kinh tế thị trường. Cụ thể, trong đăng ký giao dịch, tính ưu tiên tạo ra sự cạnh tranh công bằng về lợi ích khi xuất hiện người thứ ba (VD: Đăng ký thế chấp ở Pháp và Việt Nam được xem là đăng ký giao dịch thì thứ tự ưu tiên thanh toán xác định cho chủ nợ có đăng ký trước; hay đăng ký khế ước ở Hoa Kỳ thì tính ưu tiên này được áp dụng cho người mua có đăng ký trước nếu có hai người cùng mua một tài sản). Còn trong đăng ký quyền đối với tài sản thì khả năng ưu tiên biểu hiện trong việc xếp hạng quyền khác đối với tài sản, tạo ra thứ bậc về quyền cho chủ thể nắm giữ, và khi có nhiều chủ thể có quyền trên đất (không phải là quyền sở hữu) thì chủ thể nào đăng ký trước sẽ được xếp hạng ưu tiên về quyền. Thậm chí, người nhận chuyển quyền chưa đăng ký chính thức, mà chỉ đăng ký thông báo ưu tiên (hay gọi là đăng ký tạm thời hoặc giữ chỗ) thì có thể đạt sự ưu tiên về quyền từ thời điểm này.

\subsection{2. Đăng ký quyền đối với tài sản có ba đặc tính khác biệt so với đăng ký giao dịch dân}

có chút khác so với Pháp, bởi việc tra cứu là bắt buộc với Công chứng viên và nếu có sự sai sót nào đó từ tra cứu ảnh hưởng đến quyền của người mua thì Công chứng viên phải chịu trách nhiệm bồi thường cho người mua (theo khoản tiền đã ký quỹ trước đó).

${ }^{19}$ Như tại Úc có nguyên tắc tính vĩnh viễn quyền bởi đăng ký, nó chỉ bị hủy bỏ khi gian lận có thể chứng minh được; Tại Pháp, chủ sở hữu hoặc chủ thể có quyền khác đối với tài sản khi đăng ký, sẽ được ghi nhận quyền đối với tài sản đó và được bảo hộ dưới nguyên tắc bất khả xâm phạm, do vậy quyền đăng ký đó chỉ có thể bị tước bỏ bởi yếu tố "đồng $y$ " từ người ngày chuyển cho người khác.

${ }^{20}$ Như, trong đăng ký quyền sở hữu đất ở Úc, thông tin các quan hệ trên đất trong "sổ đăng ký", và là chứng cứ kết luận về quyền trên đất, nếu thông tin sai lệch thì sử dụng “Quỹ bồi thuờng”. Còn tại Pháp, thông tin về quan hệ trên đất trong "sổ thế chấp", Công chứng viên có trách nhiệm tra cứu và nếu cung cấp thông tin cho bên mua sai sót thì họ có trách nhiệm bồi thường bằng khoản tiền đã ký quỹ.

${ }^{21}$ Như trong đăng ký giao dịch Hoa Kỳ, hướng tới việc cho phép công chúng tra cứu thông tin lịch sử giao dịch về đất và tự chủ thể tra cứu rút ra kết luận về sự tồn tại quyền sở hữu tài sản. Nếu người mua bi mất quyền do người bán không phải là người có quyền định đoạt thì sẽ được công ty bảo hiểm tư nhân chi trả mất quyền, nhưng với điều kiện người mua phải tham gia mua bảo hiểm. 
sự về chuyển quyền đối với tài sản

(i) Tính công khai độc quyền. Đây là cách thức công khai hóa về sự tồn tại của quyền đối với tài sản hoặc chuyển dịch thực tế về quyền, và là yếu tố nhằm tạo ra sự cạnh tranh công bằng quyền lợi trên tài sản, mà "buộc mọi chủ thể phải biết". Nếu trong đăng ký giao dịch, có thể nhiều chủ thể có cùng lợi ích được tham gia đăng ký (VD: nhiều chủ nợ đăng ký thế chấp), thì đăng ký quyền đối với tài sản là một sự phân chia quyền năng trên tài sản, nghĩa là không thể nhiều chủ thể cùng nắm giữ một quyền trên một đơn vị tài sản (VD: quyền sở hữu, quyền hưởng dụng, quyền bề mặt), mà chỉ có thể là đồng sở hữu một quyền. Do đó, tính công khai trong đăng ký quyền đối với tài sản được áp dụng nhằm xác định thứ hạng cho nhiều chủ thể nắm giữ các quyền phân chia đó. Nó hướng đến công nhận sự tồn tại của quyền, truy dẫn danh tính chủ thể nắm giữ, buộc chủ thể khác phải biết về sự tồn tại đó và chủ thể đăng ký có một sự cạnh tranh độc quyền trong phạm vi quyền đã đăng ký, tốt hơn so với chủ thể khác. ${ }^{22}$

(ii) Tính đối kháng về quyền. Đối kháng về lợi ích trong đăng ký giao dịch hướng đến đòi lại một khoản nợ/ lợi ích, mà đòi hỏi này không tước bỏ quyền thu hồi tài sản của chủ sở hữu (trừ khi CSH mất khả năng thanh toán sẽ do cơ quan có thẩm quyền tước bỏ), thì đối kháng về quyền trong đăng ký quyền đối với tài sản thể hiện sự áp đặt mạnh hơn khả năng thu hồi tài sản của chủ sở hữu. Như tại Đức và Pháp, hợp đồng xây dựng khi được đăng ký thì chủ thể đăng ký sẽ trở thành người có quyền bề mặt và cho đến khi thời hạn trong hợp đồng xây dựng chấm dứt thì chủ sở hữuđất mới thu hồi lại đất. Trong thời hạn quyền bề mặt tồn tại, nó sẽ không bị phá vỡ bởi chủ sở hữuvà ngay khi chủ đất chết hoặc định đoạt cho một chủ thể khác, tính đối kháng tiếp tục áp đặt người thứ ba - buộc tiếp nhận quyền bề mặt đã đăng ký.

(iii) Tính đối vật. Nếu đăng ký giao dịch hướng đến quan hệ có tính đối nhân - đăng ký sự kiện pháp lý (nghĩa là hướng đến đối tượng đăng ký là các tài liệu/ văn tự thể hiện nội dung thỏa thuận của các bên) Dang (2011), thì đăng ký quyền đối với tài sản hướng đến quan hệ có tính đối vật - đăng ký hệ quả pháp lý của sự kiện pháp lý (nghĩa là hướng đến đối tượng đăng ký là các quyền vô hình trên tài sản được truy dẫn đến chủ thể nắm giữ). Tuy nhiên đặc tính đối vật này (cứng rắn hay mềm mại) phụ thuộc vào hai khuynh hướng lập pháp khác nhau:

Một là, đối với hệ thống đăng ký xác lập quyền đối với tài sản (Đức, Úc). Việc đăng ký hướng đến đối tượng là toàn bộ quyền đối với tài sản, các quyền này chỉ có thể được "khai sinh" hoặc "khai tử" bằng đăng ký mà chúng ta thường gọi là đăng ký bắt buộc. Đặc trưng của hệ thống này bởi tính chất "đặc biệt" (specialty), đó là yếu tố đảm bảo tính chính xác, chắc chắn về quyền sở hữu và các quyền khác trên tài sản (Murray, 1999);

Hai là, đối với hệ thống đăng ký công bố quyền đối với tài sản (Pháp). Đăng ký cũng hướng đến đối tượng là quyền trên tài sản nhưng nó được giới hạn dưới dạng liệt kê trong BLDS Pháp. Đăng ký không nhằm "khai sinh" hoặc "tước bỏ" các quyền này, bởi triết lý này không phù hợp với nguyên tắc trong Hiến pháp và BLDS Pháp là không thể tước đoạt quyền ngoài cách duy nhất là "sự đồng ý của các bên". Do đó, đăng ký hướng tới công bố quyền và mang lại một hiệu lực đối kháng với chủ thể khác mà thường gọi là đăng ký theo yêu cầu.

Tóm lại, các đặc tính trên mang nội dung cơ bản, nhằm phân ranh đăng ký giao dịch và đăng ký quyền đối với tài sản. Nhưng việc phân biệt này mang tính tương đối nhằm giúp cho việc "cấy ghép" yếu tố pháp lý, khi hoàn thiện đăng ký tài sản ở Việt Nam. Hướng đến giải quyết tranh chấp phát sinh giữa các chủ thể đăng ký có cùng hoặc khác nhau quyền lợi trên một tài sản. Trên thực tế, vấn đề cốt lõi của hệ thống đăng ký tài sản là đáp ứng nhu cầu thông tin hiệu quả, đáng tin cậy cho giao dịch dân sự và phát triển của thị trường về tài sản (Dang, 2011), chứ không "hợp

\footnotetext{
${ }^{22}$ Như ở Úc thì chủ đất có đăng ký sẽ nhận được bảo vệ tuyệt đối hơn so với người chiếm hữu tình trạng thực tế đất.
} 
thời” nếu pháp luật đăng ký tài sản quốc gia chỉ theo đuổi duy nhất một nhánh đăng ký nào, nhất là khi đăng ký được chuyển sang dạng điện tử (VD: Đức, Thụy Điển). Khuynh hướng xây dựng hệ thống đăng ký hiện đại là kết hợp đan xen các đặc tính trong đăng ký giao dịch và đăng ký quyền, hướng đến: (i) gia tăng hiệu lực của quyền được đăng ký và giảm thiểu tác động của không đăng ký; (ii) gia tăng hiệu lực tác động của đăng ký đối với bên thứ ba ${ }^{23}$ và giải quyết trật tự xếp hạng khi tồn tại nhiều chế định đăng ký gắn với một đơn vị tài sản.

\section{Những xung đột pháp luật về thứ tự xếp hạng liên quan đến đăng ký giao dịch dân sự về chuyển quyền sở hữu bất động sản hình thành trong tương lai ở Việt Nam}

\subsection{Xung đột thứ tự đăng ký giữa đăng ký giao dịch dân sụ về chuyển quyền đối với bất động sản hình thành trong tương lai và đăng ký quyền khác đối với tài sản}

Dưới góc độ đăng ký giao dịch dân sự về chuyển quyền đối với BĐS HTTTL, thì các đối tượng đăng ký đã được tác giả làm rõ ở trên là: (i) giao dịch về chuyển đổi, chuyển nhượng, thừa kế, tặng cho quyền sử dụng đất được suy đoán là dạng “đăng ký bắt buộc đối với giao dịch dân sụ về chuyển quyền sủ dụng đất hình thành trong tương lai" với điều kiện là trước thời điểm cấp giấy chứng nhận quyền sử dụng đất chính thức; (ii) giao dịch mua bán nhà ở HTTTL là dạng "đăng ký theo yêu cầu đối với giao dịch dân sụ về chuyển quyền sở hũu nhà ở hình thành trong tuong lai" cũng với điều kiện là trước thời điểm cấp giấy chứng nhận quyền sở hữu nhà ở chính thức.

Còn dưới góc độ đăng ký quyền khác đối với tài sản, thì tại Điều 246 BLDS năm 2015 cho phép quyền đối với BĐS liền kề được xác lập "theo thỏa thuận hoạc theo di chúc" nghĩa là có thể xác lập bởi hợp đồng có đền bù hoặc hợp đồng không có đền bù, điều này là phù hợp với quy định ở Điều 171 Luật Đất đai năm 2013 là "Việc xác lập quyền sủ dụng hạn chế đối với thưa đất liền kề thưc hiện theo quy định của pháp luật dân sư và phải thực hiện đăng ký theo quy định tại Điều 95 của Luật này". Như vậy kết quả các quy định vừa nêu ta có khi có một thỏa thuận của chủ đất chia cắt "quyền sủ dụng hạn chế đối với thưa đất liền kề" thì "phải thực hiện đăng ký" theo điểm 1 khoản 4 Điều 95 Luật Đất đai năm 2013. Chính vì thế, đối tượng của đăng ký lúc này có thể hiểu theo hai cách: hoặc là “đăng ký quyền sử dụng hạn chế đối với thửa đất liền kề" nếu là đăng ký hệ quả pháp lý của sự kiện pháp lý (đây là cách hiểu theo mô hình về đăng ký quyền đối với tài sản trên thế giới); hoặc là "giao dịch chuyển quyền đối với quyền sử dụng hạn chế đối với thửa đất liền kề” nếu là đăng ký sự kiện pháp lý (đây là cách hiểu theo mô hình về đăng ký giao dịch dân sự đối với tài sản trên thế giới). Tuy nhiên, khi đối chiếu với điểm 1 khoản 4 Điều 95 Luật Đất đai năm 2013 thì đăng ký biến động đi theo hướng "Xác lập, thay đổi hoạc chấm dứt quyền sư dụng hạn chế thưa đất liền kề" nghĩa là thuộc chế định về đăng ký quyền đối với tài sản.

Vì hiện nay, Bộ luật Dân sự năm 2015 có mở rộng nội hàm về quyền khác đối với tài sản gồm quyền hưởng dụng và quyền bề mặt và quyền đối với với bất động sản liền kề, nhưng khi nhìn lại Luật Đất đai năm 2013 thì mới chỉ điều chỉnh dạng "quyền sủ dụng hạn chế thưa đất liền kề" và có quy định về "đăng ký quyền sủ dụng hạn chế thửa đất liền kề" (i) trong điểm 1 khoản 4 Điều 95. Cùng với đó là sự tồn tại của quy định về "đăng ký giao dịch dân sụ chuyển quyền sỏ hưu quyền sử dụng đất HTTTL, quyền sở hũu tài sản khác gắn liền với đất HTTTL" (ii). Đây cũng là nguyên nhân dẫn đến sự tồn tại của một xung đột pháp lý về thứ tự đăng ký giữa (i) và (ii), mà pháp luật hiện hành vẫn chưa làm rõ việc xếp hạng quyền ưu tiên nắm giữ quyền thuộc về ai để có được hệ quả đối kháng với chủ thể còn lại.

\subsection{Xung đột thứ tụ với đăng ký giữa đăng ký giao dịch dân sụv về chuyển quyền đối với bất động sản hình thành trong tương lai và đăng ký giao dịch bảo đảm}

\footnotetext{
${ }^{23}$ Chẳng hạn ở Việt Nam, đăng ký giao dịch bảo đảm mở rộng thêm tính đối kháng để gia tăng hiệu lực của giao dịch với bên thứ ba; hay ở Pháp, hợp đồng cho thuê xây dựng có thể được đăng ký công khai để ưu tiên nắm giữ quyền bề mặt.
} 
Xu thế pháp luật thế giới hiện nay là chấp nhận việc các bên sử dụng tài sản HTTTL để bảo đảm cho các nghĩa vụ (Le, 2015). Ví dụ: trong luật của Pháp, chủ đầu tư xây dựng một tòa nhà chung cư có thể thế chấp toàn bộ tòa nhà chung cư đó để vay tiền đầu tư thực hiện dự án. Người mua căn hộ chung cư cũng có quyền thế chấp căn hộ sẽ xây dựng để vay tiền mua căn hộ. Trong trường hợp này, người mua căn hộ sẽ thanh toán trực tiếp cho ngân hàng của chủ đầu tư. Lúc này, đồng thời với việc giải chấp của ngân hàng của chủ đầu tư thì ngân hàng của người mua căn hộ xác lập thế chấp đối với căn hộ. ${ }^{24}$

Ở Việt Nam cũng thể hiện xu thế đó thông qua sự ghi nhận tại khoản 3 Điều 295 BLDS năm 2015, tài sản HTTTL cũng là đối tượng của giao dịch bảo đảm như sau: "3. Tài sản bảo đảm có thể là tài sản hiện có hoạc tài sản hình thành trong tuoong lai." Với quy định trên, tài sản HTTTL được thừa nhận là một dạng của tài sản bảo đảm và được pháp luật dân sự cho phép tham gia lưu thông vào thị trường nhằm phát huy lợi ích tiềm năng của chúng trong tương lai, trước khi nó được hình thành về mặt vật lý (điểm a khoản 2, Điều 108 BLDS năm 2015) hoặc trước khi chủ thể nhận chuyển quyền sở hữu được xác lập quyền sở hữu chính thức đối với tài sản đã hình thành (điểm b khoản 2, Điều 108 BLDS năm 2015).

Xem xét các quy định về đăng ký giao dịch bảo đảm đối với tài sản HTTTL, thì tài sản không thể là đối tượng của mọi biện pháp bảo đảm, mà chỉ có thể là đối tượng bảo đảm của một số biện pháp cụ thể và theo những điều kiện xác định. Bởi lẽ, tài sản HTTTL không thể dùng để ký quỹ hay ký cược, đặt cọc vì bản chất của các biện pháp đó quy định đối tượng bảo đảm phải là tiền (ký quỹ), hoặc tiền/ giấy tờ có giá/ tài sản là vật có giá trị khác, và một quyền tài sản cũng không thể dùng để cầm cố hay đặt cọc (Le, 2015). Chính vì thế, tài sản HTTTL có sự giới hạn khi tham gia vào giao dịch bảo đảm và được phép đăng ký bảo đảm để hưởng quyền ưu tiên thanh toán, hay còn gọi là quyền thu hồi tài sản bảo đảm để đảm bảo thanh toán.

Tại Điều 298 BLDS năm 2015 quy định về đăng ký biện pháp bảo đảm như sau:

“1. Biện pháp bảo đảm được đăng ký theo thỏa thuận hoặc theo quy định của luật.

Việc đăng ký là điều kiện để giao dịch bảo đảm có hiệu lực chỉ trong truờng hợp luật có quy dịh.

2. Truờng hợp được đăng ký thì biện pháp bảo đảm phát sinh hiệu lục đối kháng với người thứ ba kể tù̀ thời điềm đăng ký.

3. Việc đăng ký biện pháp bảo đảm được thực hiện theo quy định của pháp luật về đăng ký biện pháp bảo đảm."

Với quy định trên thì hệ quả của việc đăng ký bảo đảm thành công thì sẽ phát sinh hệ quả "đối kháng với người thư ba", và cũng tại Điều 297 BLDS năm 2015 cụ thể hóa thế nào là "hiệu lục đối kháng với nguời thứ ba" như sau:

“1. Biện pháp bảo đảm phát sinh hiệu lực đối kháng với người thư ba tù khi đăng ký biện pháp bảo đảm hoặc bên nhận bảo đảm nắm giữ hoặc chiếm giũu tài sản bảo đảm.

2. Khi biện pháp bảo đảm phát sinh hiệu lực đối kháng với người thứ ba thì bên nhận bảo đảm được quyền truy đòi tài sản bảo đảm và được quyền thanh toán theo quy định tại Điều 308 của Bộ luật này và luật khác có liên quan."

\footnotetext{
${ }^{24}$ Michel. G. (do Nhà Pháp luật Việt - Pháp ghi lại). Một số quy định pháp luật Cộng hòa Pháp về các biện pháp bảo đảm thực hiện nghĩa vụ dân sự. Tại cuộc Tọa đàm Sưa đổi Bộ luật Dân sụ 2005 do Nhà Pháp luật Việt - Pháp tổ chức các ngày 11 và 12/01/2012,

http://moj.gov.vn/ct/tintuc/Lists/Nghin\%20cu\%20trao\%20i/View_Detail.aspx?ItemID=4454.
} 
Tuy nhiên tổng hợp các điều khoản trên cho kết quả là "hiệu lực đối kháng” mà người đăng ký được hưởng sẽ có phạm vi thực thi với 03 chủ thể là: (i) người thứ ba; (ii) bên nhận bảo đảm nắm giữ; (iii) bên chiếm giữ tài sản bảo đảm. Tuy nhiên, "người thứ ba" ở đây là thuật ngữ rộng bao hàm tất cả ai không phải là người đăng ký, nhưng trong đó có tồn tại người thứ ba là người cũng tham gia và một chế định đăng ký khác cũng gắn liền với tài sản bảo đảm đó. Do đó, việc quy định "hiệu lực đối kháng" trong trường hợp này là chưa hợp lý, và chưa được tính đến sự xung đột hệ quả về quyền đòi lại tài sản ở Điều 168 BLDS năm $2015,{ }^{25} \mathrm{khi}$ "người thứ ba" có tham gia một đăng ký nắm giữ quyền sở hữu và quyền khác đối với tài sản (VD: quyền bề mặt, quyền hưởng dụng, quyền đối với BĐS liền kề, quyền lưu cư,...) được thừa nhận ở Điều 106 BLDS năm $2015^{26}$ hoặc có tham gia đăng ký một giao dịch dân sự về chuyển quyền sở hữu BĐS HTTL nói riêng và chuyển quyền đối với BĐS nói chung được ghi nhận trong Điều 95 Luật Đất đai.

Như vậy, cách quy định về "hiệu lục đối kháng” trong BLDS năm 2015 hiện nay đã không tính đến vấn đề xung đột giữa nhiều người nắm giữ quyền thu hồi tài sản bởi đăng ký (có thể từ đăng ký bảo đảm, từ đăng ký nắm giữ quyền đối với tài sản và đăng ký giao dịch dân sự về chuyển quyền đối với tài sản). Tuy nhiên, cần thấy rằng, $\mathrm{BĐS} \mathrm{HTTTL} \mathrm{có} \mathrm{nhiều} \mathrm{tính} \mathrm{chất} \mathrm{đặc} \mathrm{biệt:} \mathrm{giá} \mathrm{trị}$ tài sản đang tiến triển và chưa xác định cụ thể, chính xác; khả năng hoàn thiện, khả năng được xác lập quyền sở hữu là chưa chắc chắn, nên pháp luật không chỉ cần xây dựng các quy định về điều kiện cụ thể làm tiêu chí để bên nắm giữ được sử dụng tài sản làm đối tượng trong giao dịch bảo đảm (Le, 2015), mà còn "xếp hạng quyền uu tiên thu hồi tài sản"27 hay "xếp hạng quyền uu tiên truy đòi đối tương đăng $k y$ "28 đó thông qua đăng ký so với chủ thể có cùng quyền năng khác trên tài sản đó.

Vấn đề đặt ra là trong cùng bản chất là giao dịch dân sự, thì giữa "chủ thể có đăng ký giao dịch dân sư về chuyển quyền sở hữu BĐS HTTTL" với "chủ thể đăng ký giao dịch bảo đảm BĐS HTTTL" thì khi đăng ký thành công và phát sinh hiệu lực đối kháng, thì việc xếp hạng quyền ưu tiên thu hồi tài sản để đảm bảo cho nghĩa vụ theo nguyên tắc nào? Việc xếp hạng trong đăng ký

\footnotetext{
${ }^{25}$ Theo Điều 168 BLDS năm 2015 thì "Chủ sở hũu đuợc đòi lại động sản phải đăng ký quyền sở hũu hoặc bất động sản tù̀ nguoòi chiếm hữu ngay tình, trù truờng hợp quy định tại khoản 2 Điều 133 của Bộ luật này."

${ }^{26}$ Theo Điều 106 BLDS năm 2015 thì "1. Quyền sở hữu, quyền khác đối với tài sản là bất động sản được đăng ký theo quy định của Bộ luật này và pháp luật về đăng ký tài sản. 2. Quyền sở hũu, quyền khác đối với tài sản là động sản không phải đăng ký, trù̀ truòng hơp pháp luật về đăng ký tài sản có quy định khác. 3. Việc đăng ký tài sản phải đurợ công khai."

2. Quyền sở hữu, quyền khác đối với tài sản là động sản không phải đăng ký, trừ trường hợp pháp luật về đăng ký tài sản có quy định khác.

3. Việc đăng ký tài sản phải được công khai.

${ }^{27}$ Việc xếp hạng đăng ký trước hoặc sau là để đảm bảo sự cạnh tranh công bằng giữa nhiều chủ thể có cùng đăng ký quyền trên một tài sản bảo đảm. Chẳng hạn, ngân hàng đăng ký bảo đảm là để đảm bảo nghĩa vụ thanh toán khoản nợ của con nợ đối với mình, sẽ xung đột với người mua tài sản có đăng ký giao dịch mua bán, thì lúc này việc xếp hạng quyền thu hồi tài sản ưu tiên thuộc về ai sẽ được quyết định bởi việc Ngân hàng hay người mua, ai đăng ký trước thì ưu tiên thu hồi tài sản nhằm đảm bảo lợi ích của bên đó trước.

${ }^{28}$ Ở đây, chúng ta cần phân biệt quyền truy đòi tài sản khác với quyền thu hồi tài sản. Khi chủ thể có quyền truy đòi quyền sở hữu tài sản, nghĩa là chủ thể đó là người nắm giữ quyền sở hữu tài sản, nhưng tài sản hiện hữu thì họ lại không nắm giữ về mặt vật lý, do đó họ có quyền truy đòi để chiếm giữ về mặt vật lý nhằm khôi phục hoàn toàn quyền năng sở hữu của họ. Còn quyền thu hồi tài sản ở đây là khả năng gây ức chế quyền chiếm hữu và quyền khác đối với tài sản mà chủ sở hữu hoặc chủ thể khác đang nắm giữ về mặt vật lý, để mang lại sự thỏa mãn quyền lợi thông qua công cụ ưu tiên bảo vệ quyền bởi thiết chế đăng ký. (VD như: người đăng ký bảo đảm có quyền yêu cầu phát mãi tài sản bảo đảm để thanh toán khoản nợ; hoặc người có đăng ký giao dịch chuyển dịch quyền có quyền yêu cầu người khác chấm dứt hành vi xâm phạm đến tài sản ở thời điểm mà người mua quyền nhưng chưa được cấp giấy chứng nhận quyền). Trên thực tế, quyền thu hồi tài sản trong thiết chế đăng ký bảo đảm được cụ thể hóa bởi các quy định của luật thủ tục về "xử lý tài sản bảo đảm" của thiết chế đăng ký bảo đảm, còn quyền thu hồi tài sản trong thiết chế đăng ký giao dịch chuyển quyền sở hữu thì chưa được cụ thể hóa, dẫn đến nhiều tranh chấp xảy ra giữa người thứ ba và các bên trong quan hệ bảo đảm hay giữa người nhận bảo đảm trong quan hệ mua bán tài sản của chủ sở hữu với người khác.
} 
hiện chỉ tồn tại trong quan hệ có nhiều chủ nợ có đăng ký bảo đảm và nguyên tắc xếp hạng thứ tự đăng ký theo điểm a khoản 1 Điều 308 BLDS năm $2015,{ }^{29}$ dựa trên yếu tố "thứ tư xác lập hiệu lực đối kháng". Hay nói cách khác là yếu tố "thứ tư xác lập hiệu lục đối kháng" chỉ áp dụng giải quyết mâu thuẫn nội bộ để xếp hạng quyền lợi thanh toán giữa nhiều "chủ thể đăng ký giao dịch bảo đảm" với nhau, mà không áp dụng cho trường hợp mâu thuẫn giữa "chủ thể có đăng ký giao dịch dân sụ về chuyển quyền sở hũu" với "chủ thể đăng ký giao dịch bảo đảm.

\section{Kinh nghiệm nước ngoài và tầm nhìn về xây dựng pháp luật cho Việt Nam}

\subsection{Kinh nghiệm nước ngoài về đăng ký}

Ở Pháp, dưới sự phát triển của thương mại và kinh doanh đòi hỏi một cuộc cải cách nhằm đảm bảo an toàn cho người mua quyền sở hữu BĐS. Họ cần phải biết liệu họ có đang thật sự thực hiện hành vi mua bán với chủ sở hữu tài sản, liệu chủ sở hữucó ghép thêm các quyền khác vào tài sản hay không, không chỉ đối với quyền đối một khoản nợ mà cả quyền hưởng dụng thu lợi, tiện ích và hợp đồng thuê dài hạn. ${ }^{30}$ Do đó, BLDS Pháp thiết lập đăng ký các loại quyền đối với BĐS (Điều 2521 BLDS Pháp ${ }^{31}$ ) như là cách để giúp người mua quyền sở hữu BĐS nhận biết được quyền đó đang tồn tại. Hệ quả của đăng ký quyền là buộc người mua muốn giành lại toàn bộ chủ quyền đối với $\mathrm{BĐS}$, thì phải thỏa hiệp với chủ thể đang nắm giữ quyền: hoặc chấm dứt, hoặc chuyển giao quyền cho người mua. Nhưng vì đăng ký quyền này chỉ mang lại ưu tiên về đối kháng quyền cho người thứ ba, chứ không kết luận quyền đó là độc quyền thuộc về người đăng ký, nên vẫn có khả năng quyền này tồn tại theo ý chí định đoạt chủ sở hữu mà chưa đăng ký. Do đó, Pháp xếp hạng bằng cách nộp bản tóm tắt đăng ký để nhập vào sổ đăng ký thế chấp. Nhưng không có sự phân biệt giữa thời điểm nộp đơn với thời điểm ghi vào sổ để xác định thứ tự xếp hạng. Hai sự kiện này được hợp nhất để đưa ra một ngày duy nhất, ngày nộp lưu chiểu (the date of deposit). Nhưng, với đặc quyền tài sản (một loại phí $\mathrm{BĐS}$ với hiệu quả gần giống như thế chấp) lại trái ngược đăng ký thế chấp. Bởi nó không mang thuộc tính xếp hạng như đăng ký thế chấp, mà đặc quyền người bán hoặc người cho vay (moneylender) chỉ bị mất thứ hạng kể từ ngày giao dịch đó xác lập. Người mua lúc này được xếp hạng, nhưng tồn tại trong vòng 02 tháng, kể từ ngày giao dịch đó xác lập đăng ký phải được thực hiện. Riêng, tại Alsace-Moselle, Điều 1 Đạo luật ngày 4/3/2002 quy định "Ngày và thứ hạng đăng ký được xác định bằng cách tham chiếu đến việc nộp đơn yêu cầu đưa vào sổ đăng ký".

Nhưng ở Đức có sự khác biệt. Xuất phát từ nguyên tắc tính pháp lý của quyền thực (the numerus clausus of real rights) chi phối sự hình thành quyền sở hữu BĐS trong sổ đăng ký, nên việc xác lập các quyền khác đối với tài sản sẽ bị áp đặt bởi nguyên tắc bắt buộc có sự liên quan đến nội dung định sẵn trong sổ đăng ký (the compulsion of types in regard to content). Khi có đăng ký, quyền khác đối với tài sản thuộc về chủ thể khác mới bắt đầu phát sinh tính pháp lý từ đây. ${ }^{32}$ Trên nền tảng đó, quyền khác đối với tài sản được "khai sinh" theo một nguyên tắc nữa, là nguyên tắc về sự rõ ràng và xác định (the principle of clarity and definiteness) trong sổ đăng ký. Tính rõ ràng được hiểu là các quyền khác đối với tài sản đó phải rõ đối với tài sản (là tài sản hữu hình hoặc

\footnotetext{
${ }^{29}$ Theo điểm a khoản 1 Điều 308 BLDS năm 2015 thì: "các biện pháp bảo đảm đều phát sinh hiệu lưc đối kháng với người thứ ba thì thư tự thanh toán được xác định theo thư tư xác lập hiệu lực đối kháng”.

${ }^{30}$ Philitre, D. , Philitre S., tlad, tr. 323.

${ }^{31}$ Xem Điều 2521 Bộ luật Dân sự Pháp Phiên bản có hiệu lực vào ngày 06 tháng 2 năm 2021, https://www.legifrance.gouv.fr/codes/section_lc/LEGITEXT000006070721/LEGISCTA000006150510/\#LEGISCT A000006150510, truy cập ngày 30/12/2020.

32 Tuy nhiên cũng có ngoại lệ không cần đăng ký hướng đến các quyền thực liên quan đến tính công bằng của cá nhân, như 03 trường hợp về quyền địa dịch: là quyền sử dụng hạn chế $\mathrm{BĐS}$; là quyền thực tế để chống lại những hành động nhất định đối với bất động sản bị cản trở; và cuối cùng như là một quyền thực loại trừ bất kỳ quyền liên quan. Harald, $\mathrm{W} .$, tldd, tr. 226.
} 
quyền tài sản); và tính xác định là phạm vi và nội dung của các loại quyền đều phải được nhận biết đầy đủ. Chính các nguyên tắc này, giúp cho các loại quyền khác đối với tài sản trở nên chắc chắn, có hiệu lực và tham gia vào xếp hạng kể từ thời điểm ghi vào sổ đăng ký. Cụ thể là theo Điều 124 Luật Sổ địa bạ Đức 1897 sửa đổi 2004, thì “Thú bậc các quyền được ghi lại theo quy định pháp luật hiện hành tại thời điểm phát sinh quyền, và nếu không thể xác định được thư tự, thì xác định theo thời điểm các quyền này được khai báo." và đạo luật còn dành sự quan tâm lớn, từ Điều 90 đến Điều 115, để giải quyết tranh chấp thứ bậc giữa các chủ thể trên một đơn vị tài sản.

\subsection{Tầm nhìn về xây dung pháp luật cho Việt Nam}

Với những phân tích về 02 xung đột trong thứ tự ưu tiên đăng ký trên thì vấn đề cần xác định rõ là thiết lập cơ chế nào để bảo vệ chủ thể nhận chuyển quyền sở hữu khi bên bán còn đang nắm giữ quyền sở hữu mà chưa đăng ký chuyển quyền sở hữu chính thức; làm thế nào để bảo vệ chủ thể nhận chuyển quyền sở hữu, khi họ không biết được rằng bên bán có đang thiết lập giao dịch một dân sự khác hoặc chuyển quyền khác đối với BĐS cho người khác mà không thông qua ý kiến của họ hay không; và/ hoặc tồn tại thêm bên thứ ba có đăng ký bảo đảm? Theo kinh nghiệm các nước cho thấy, việc xếp hạng quyền thu hồi tài sản thông qua "đăng ký ưu tiên" đối với BĐS nói chung và BĐS HTTTL nói riêng là cần thiết nhằm giải quyết hai vấn đề xung đột về đăng ký mà tác giả đề cập trên, và được một số nước trên thế giới thể chế bằng luật về đăng ký (VD: Đức, Pháp, Úc).

Do đó, ở Việt Nam, tác giả đề xuất, nên lựa chọn phương án xây dựng một đạo luật duy nhất, hướng đến nguyên tắc vận hành hệ thống đăng ký, nghĩa là hướng đi chủ động mà các quan hệ trên tài sản sẽ phải phụ thuộc vào các nguyên tắc vận hành của hệ thống. Hướng đi này cũng là nhu cầu đã được nêu tại khoản 1 Điều 106 BLDS năm 2015, mong muốn xây dựng thiết chế độc lập về đăng ký quyền đối với tài sản, hướng đến đối tượng đăng ký là "quyền sở hưu, quyền khác đối với tài sản", nhằm bảo vệ các quyền năng này bởi đăng ký, chứ không dừng ở đăng ký để quản lý hành chính như hiện nay. Do đó, Quốc hội nên thảo luận, nghiên cứu, sớm có kế hoạch xây dựng “Luật về Các biện pháp đăng ký tài sản” trong đó xác định rõ: dân sự;

(1) Phân biệt rõ đối tượng trong đăng ký quyền và đối tượng trong đăng ký là giao dịch

(2) Xác định rõ hệ quả của đăng ký giữa hai cơ chế đăng ký bắt buộc và đăng ký theo yêu cầu (dựa trên cơ sở nội hàm, mục đích, thời điểm đăng ký và loại quyền được đăng ký). Đồng thời xếp hạng thứ tự ưu tiên của các đối tượng đăng ký trên cơ sở luật định;

(3) Nếu là đăng ký quyền đối với tài sản, thì trừ quyền sở hữu, còn lại quyền khác đối với tài sản khi tham gia đăng ký cần tính đến việc xếp hạng dựa trên thứ tự đăng ký trước và sau nhằm giải quyết xung đột về tính đối kháng quyền nắm giữ. Tuy nhiên, cũng cần chú ý đến xếp hạng về đăng ký quyền khác đối với tài sản phát sinh từ thỏa thuận (VD: quyền về lối đi theo thỏa thuận) và phát sinh bắt buộc theo quy định của pháp luật (VD: như tính vây bọc tự nhiên của quyền về lối đi đối với BĐS liền kề) đề cập trong BLDS năm 2015. Theo tác giả, hiệu lực của đăng ký quyền khác đối với tài sản phát sinh bắt buộc theo quy định của pháp luật được ưu tiên nhất so với quyền khác đối với tài sản phát sinh theo thỏa thuận, hoặc so với đăng ký giao dịch dân sự về chuyển quyền, hoặc so với đăng ký giao dịch bảo đảm. Bởi hướng đi này là đảm bảo lợi ích thực tế mà "tạo hóa" của tài sản đó tạo ra, so với lợi ích giả định từ pháp luật trong môi trường chuyển dịch tài sản tạo ra.

(4) Nếu là đăng ký giao dịch dân sự về chuyển quyền với đăng ký giao dịch bảo đảm thì cần tính đến việc xếp hạng dựa trên thứ tự đăng ký trước và sau nhằm giải quyết xung đột về tính đối kháng quyền thu hồi tài sản nói chung và BĐS HTTTL nói riêng; 
(5) Cuối cùng là giải quyết xung đột tồn tại giữa cả 03 loại: đăng ký quyền khác đối với tài sản, đăng ký giao dịch bảo đảm và đăng ký chuyển quyền sở hữu trên cùng một đơn vị tài sản nói chung và BĐS HTTTL nói riêng. Tác giả đề xuất giải quyết xung đột theo nguyên tắc các đăng ký hạn chế quyền sở hữu phải được ưu tiên thực thi trước trên cơ sở các xếp hạng đã nêu trên, rồi mới đến thực thi quyền sở hữu sau.

\section{Tài liệu tham khảo}

Dang, A. Q (2011). Hệ thống đăng ký đất đai theo pháp LĐĐ Việt Nam và Thụy Điển [Land registration system according to the Vietnamese and Swedish Labor Laws] (Doctoral dissertation, Lund University, Sweden).

Dang, P. T. (2020). Đăng ký quyền sở hữu căn hộ chung cư theo yêu cầu và một số kiến nghị nhằm hoàn thiện pháp luật [Register the right to own an apartment as required and some recommendations to improve the law]. Tạp chi Khoa hoc pháp lý Việt Nam, 3.

Dongwoo, Y., \& Richard, H. S. (2010). Property rights and financial development: The legacy of Japanese colonial institutions. NBER Working Paper, 16551. Retrieved June 1, 2018, from http://www.nber.org/papers/w16551

Foucault, M. (1969). The archeology of knowledge. Retrieved May 2, 2019, from https://thecharnelhouse.org/wp-content/uploads/2015/01/michel-foucault-the-archaeologyof-knowledge.pdf

Hanstad, T. (1998). Designing land registration systems for developing countries. American University International Law Review, 13(3), 647-703.

Harald, W. (2012). The German "Grundbuchordnung": History, principles and future about land registry in Germany. Zeitschrift für Geodäsie, Geoinformation und Landmanagement (ztv), 137(4).

Larsson, G. (1991). Land registration in developing countries. Boston, MA: Addison-Wesley.

Le, M. H. (2015). Hoàn thiện các quy định về giao dịch bảo đảm trong Bộ luật Dân sự năm 2015 [Complete regulations on secured transactions in the Civil Code 2015]. Tạp chí Khoa hoc pháp $l y, 1$.

Murray, J. R. B. J. (1999). German real property law and the conclusive land title register (Doctoral dissertation, The University of Melbourne, Australia).

Nguyen, H. K. N. (2018). Hợp đồng mua bán nhà ở hình thành trong turong lai theo pháp luật Việt Nam [Contracts for purchase and sale of houses to be formed in the future according to the laws of Vietnam] (Unpublished master's thesis). University of Law, Ho Chi Minh, Vietnam.

Quốc hội. (2014). Luật Kinh doanh bất động sản [Law on Real Estate Business]. Retrieved May 3, 2019, from https://thuvienphapluat.vn/van-ban/Thuong-mai/Luat-Kinh-doanh-bat-dong-san2014-259722.aspx

Quốc hội. (2015a). Luật Nhà ỏ [Housing law]. Retrieved May 4, 2019, from https://thuvienphapluat.vn/van-ban/Bat-dong-san/Luat-nha-o-2005-56-2005-QH116918.aspx

Quốc hội. (2015b). Bộ Luật Dân sụ [Social legal]. Retrieved May 5, 2019, from https://thuvienphapluat.vn/van-ban/Quyen-dan-su/Bo-luat-dan-su-2015-296215.aspx

Samantha, H. (2001). Principles of property law (2nd ed.). London, UK: Cavendish Publishing Limited. 
Soto, H. D. (2001). The mystery of capital. Retrieved May 10, 2019, from International Monetary Fund website: https://www.imf.org/external/pubs/ft/fandd/2001/03/desoto.htm

Vu, D. N., \& Tuan, D. T. (2009). Luận bàn về thế chấp tài sản hình thành trong tương lai [Discussion about mortgage of property to be formed in the future]. Tạp chí Dân chủ và Pháp luật, 10. 